\title{
Initial development of Tahiti acid lime trees on different rootstocks in the semiarid region of Ceará, Brazil
}

\author{
Débora Costa Bastos ${ }^{1}$, Kássio Ewerton Santos Sombra ${ }^{2}$, Francisco Leandro Costa Loureiro ${ }^{2}$, \\ Alexandre Caique Costa e Silva² \& Orlando Sampaio Passos ${ }^{3}$
}

\section{SUMMARY}

Tahiti acid lime is the most cultivated lime tree in the Northeast region of Brazil. The present study aimed to investigate the initial development of CNPMF 01 Tahiti acid lime tree clones grafted on rootstocks in the semiarid region of Ceará. The experiment was arranged in a completely randomized design, using the nuclear clones CNPMF 01 Tahiti acid lime on different rootstocks, according to the treatments: T1 - Rangpur Santa Cruz lime lime; T2 - Sunki Tropical Tangerine; T3 - Citrandarin Indio; T4 - Citrandarin Riverside; T5 - Swingle Citrumelo. Four seedlings were transplanted per treatment, in a soil classified as Typical Orthic Hydromorphyc Vertisol (SiBCS), spaced 5 x $4 \mathrm{~m}$. We evaluated the height $(\mathrm{H})$, diameter between plants and between rows ( $\mathrm{Dl}$ and $\mathrm{Dr}$ ), using the data to calculate the average canopy volume $\left(\mathrm{V}^{3}\right)$, and measured the diameter of the stem $5 \mathrm{~cm}$ above $(\mathrm{D} \uparrow)$ and below (D $\downarrow$ ) grafting, conducting biometric evaluations at 18, 24 and 30 months after transplantation. The treatments $\mathrm{T} 1$ and $\mathrm{T} 4$ showed the best results, reaching the following final values: height: $\mathrm{T} 1=2.12 \mathrm{~m}$ and $\mathrm{T} 4=2.12 \mathrm{~m}$; diameter between plants: $\mathrm{T} 1=3.53 \mathrm{~m}$ and $\mathrm{T} 4=3.17 \mathrm{~m}$; diameter between lines: $\mathrm{T} 1=3.63 \mathrm{~m}$ and $\mathrm{T} 4=3.17 \mathrm{~m}$; canopy volume: $\mathrm{T} 1=14.40 \mathrm{~m}^{3}$ and $\mathrm{T} 4=11.29 \mathrm{~m}^{3}$; stem diameter $(\mathrm{D} \uparrow$ and $\mathrm{D} \downarrow)$ : $\mathrm{T} 1=104.40 \mathrm{~mm}$ and $114.16 \mathrm{~mm}, \mathrm{~T} 4=80.76 \mathrm{~mm}$ and $74.56 \mathrm{~mm}$. The Citrandarin Riverside and Rangpur Santa Cruz lime rootstocks induced greater adaptation and vegetative development of the nuclear clone of CNPMF 01 Tahiti acid lime tree, as reported in the literature, while Swingle Citrumelo led to the lowest measures.

Index terms: biometrics, citrus, diversification, vegetative development.

\section{Desenvolvimento inicial da limeira ácida Tahiti sobre diferentes porta-enxertos no semiárido do Ceará, Brasil}

\section{RESUMO}

A limeira ácida Tahiti é a limeira mais plantada na região Nordeste. O presente trabalho teve objetivo de verificar o desenvolvimento inicial do clone de limeira ácida Tahiti CNPMF 01 sobre porta-enxertos no semiárido do Ceará. O delineamento foi inteiramente casualizado,

\footnotetext{
${ }^{1}$ Embrapa Semiárido, Empresa Brasileira de Pesquisa Agropecuária - EMBRAPA, Petrolina, PE, Brazil

2 Instituto Federal de Educação, Ciência e Tecnologia do Ceará - IFCE, campus Limoeiro do Norte, Limoeiro do Norte, CE, Brazil

${ }^{3}$ Centro Nacional de Pesquisa de Mandioca e Fruticultura - CNPMF, Empresa Brasileira de Pesquisa Agropecuária - EMBRAPA, Cruz das Almas, BA, Brazil

Corresponding author: Débora Costa Bastos, Embrapa Semiárido, Empresa Brasileira de Pesquisa Agropecuária - EMBRAPA, BR 428 KM 152 s/n, CP 23, Zona Rural, CEP 56302-970, Petrolina, PE, Brazil. E-mail: debora.bastos@embrapa.br
} 
utilizando o clone nuclear CNPMF 01 sobre diferentes porta-enxertos, listando-se os tratamentos: T1-Limão Cravo Santa Cruz; T2-Tangerina Sunki Tropical; T3-Citrandarin Índio; T4-Citrandarin Riverside; T5-Citrumelo Swingle, transplantando-se quatro mudas por tratamento em Vertissolo Hidromórfico Órtico Típico (SiBCS), espaçadas 5 x 4 m. Avaliaram-se as alturas $(\mathrm{H})$, diâmetros entre plantas e entre linhas (Dl e Dr), utilizando os dados para cálculo do volume médio da copa $\left(\mathrm{V}^{3}\right)$, além de mensurar o diâmetro do caule $5 \mathrm{~cm}$ acima $(\mathrm{D} \uparrow)$ e abaixo $(\mathrm{D} \downarrow)$ da enxertia, realizando-se avaliações biométricas aos 18, 24 e 30 meses após o transplantio. Os Tratamentos T1 e T4 apresentaram os melhores resultados durante a avaliação, atingindo os seguintes valores finais: altura: T1=2,12 m e T4=2,12 m, diâmetro entre plantas: T1=3,53 m e T4=3,17 m, diâmetro entre linhas: T1=3,63 m e T4=3,17 m, Volume de copa: $\mathrm{T} 1=14,40 \mathrm{~m}^{3}$ e T4=11,29 m³ , diâmetros de caule (D $\uparrow$ e $\left.\mathrm{D} \downarrow\right)$ : $\mathrm{T} 1=104,40 \mathrm{~mm}$ e $114,16 \mathrm{~mm}, \mathrm{~T} 4=80,76 \mathrm{~mm}$ e $74,56 \mathrm{~mm}$. Os porta-enxertos Citrandarin Riverside e Limão Cravo Santa Cruz induziram maior adaptação e desenvolvimento vegetativo ao clone nucelar CNPMF 01 da limeira ácida Tahiti como relatado na literatura, enquanto, o Citrumelo Swingle induziu aos menores resultados.

Termos de indexação: biometria, citros, diversificação, desenvolvimento vegetativo.

\section{INTRODUCTION}

Tahiti (Citrus latifolia Tanaka) is a cultivar of the most widespread acid lime in Brazil, in phase of expansion in the Northeast of the country in view of its good adaptation to the edaphoclimatic conditions of the region. Tahiti acid lime has its origin in Persia, now Iran, in Tahiti Island. Fruits mature throughout year in irrigated plantations (Stuchi \& Cyrillo, 1998; Almeida \& Passos, 2011; Cunha Sobrinho et al., 2013). The consumption of acid lime in various forms of "caipirinha" juices has been appreciated in all regions of the world, for its acidity, pleasant odor and less dense bark (Durigan et al., 2005). Its many benefits include therapeutic effects, such as detoxification of the body, and high content of vitamin $\mathrm{C}$, when used in drinks, for the presence of ascorbic acid (Trucom, 2004).

Tahiti acid lime tree plantations have low diversity, for they are based on a few selected toppings, particularly the IAC-5 or Peruano and the Quebra-galho. However, it is possible to obtain a greater diversity from selections, either from canopies or rootstocks, especially using the nuclear clones CNPMF 2000 and CNPMF 2001 grafted on Rangpur lemon (C. limonia Osbeck.), resulting in low productive life of these combinations due to the high susceptibility of Rangpur lemon to various biotic and abiotic stresses, such as Phytophthora spp. gummosis. This disease affects practically all citrus plants in the country (Cunha Sobrinho et al., 2013) and has been responsible for the decline of citrus in the Baixo Jaguaribe, in the semiarid region of Ceará. Citrus trees were planted in this region mainly in a family farming system, using empirical methods, through seminal seedlings (feet) and irrigation by flooding, and in the 1980s, plantations were attacked by gummosis, which proliferated and effected $90 \%$ of the citrus orchards in the region, known as " Russas' oranges", highly susceptible to the disease (Passos et al., 2013; Sombra et al., 2015).

CNPMF 01 Tahiti acid lime is a nuclear clone obtained at EMBRAPA Mandioca and Fruticultura, evaluated in successive years for aspects such as vigor, productivity and plant health, characterized by rounded and medium scion, producing small ovoid fruits, weighting $108 \mathrm{~g}$ on average with $40 \%$ of juice and without seeds, total soluble solids (TSS) of 7.6\%, total acidity (TA) of $6.5 \%$ and TSS/TA of 1.2 , with smooth and deep green bark, and uniform pulp (Soares Filho et al., 2012)

The present study aimed to evaluate the initial vegetative development of Tahiti acid lime on different citrus rootstocks under the semiarid conditions of Ceará.

\section{MATERIAL AND METHODS}

The research was conducted between 2013 and 2016 in the Citrus Experimental Area-Sítio Pau Branco, located in the rural area of Russas, Ceará, Brazil, located in the geographic coordinates $4^{\circ} 53^{\prime} 0.10^{\prime \prime} \mathrm{S}, 37^{\circ} 55^{\prime} 1.20^{\prime}$ ' W, with an altitude of approximately $19 \mathrm{~m}$. Russas is a city of Ceará located in the mesoregion of Jaguaribe Valley, at the geographic coordinates $4^{\circ} 56^{\prime} 24^{\prime}$ ' S, 37 $58^{\prime} 33^{\prime \prime} \mathrm{W}$, with an average altitude of $20.51 \mathrm{~m}$. The climate of the region is classified as dry and very hot, of the BSw ' $h$ ' type (Köppen). The average annual temperature is $28.5^{\circ} \mathrm{C}$, with a minimum of $22^{\circ} \mathrm{C}$ and a maximum of $35^{\circ} \mathrm{C}$, and the average annual rainfall is $772 \mathrm{~mm}$. The useful plants used in the experiment were provided by EMBRAPA Semiárido, in the form of changes in school, through 
the Active Citrus Germplasm Bank from EMBRAPA Mandioca e Fruticultura, located in Cruz das Almas, Bahia, Brazil. A completely randomized design was used in the study, using the CNPMF 01 Tahiti acid lime clone on five different rootstocks, with four replications. The treatments were: T1 - Rangpur Santa Cruz lime; T2 - Sunki Tropical Tangerine; T3 - Citrandarin Indio; T4 - Citrandarin Riverside; T5 - Swingle Citrumelo. The useful plants were transplanted into previously dug pits $(40 \times 40 \times 40 \mathrm{~cm})$, distributed at a dense spacing of $5 \times 4 \mathrm{~m}$ in Typical Hydromorphic Orthic Vertisol (SiBCS) which was previously mechanized and corrected, using physical and chemical analyses of the soil as a reference (Ribeiro et al., 1999). in a proportion of 20 liters per hole. It was used An irrigation system located was placed, sized so as to supply the demand of the crop, in addition to the completion of sampling for plant management.

Biometry was performed 18, 24 and 30 months after transplantation, measuring the height up to the tree apex $(\mathrm{H})$; canopy diameter in the direction between plants and between rows (Dl and Dr) using a measuring tape graded in millimeters, and average canopy volume $\left(\mathrm{V}^{3}\right)$, through the equation: $\mathrm{V}^{3}=(\pi / 6) \times \mathrm{H} \times \mathrm{Dl} \times \mathrm{Dr}$, as described by Fallahi \& Rodney (1991). We also measured the stem diameter $5 \mathrm{~cm}$ below and above the grafting line of useful plants, by calculating the compatibility ratio (IC) between the rootstock and scion, being considered fully compatible in cases of ratios equivalent to 1 (Simonetti, 2015; Rodrigues et al., 2016)

The data obtained for all variables were subjected to analysis of variance (ANOVA), and in cases of significant difference, means were compared by the Scott-Knott test at $5 \%$ probability $(\mathrm{p} \leq 0.05)$, using the statistical software ASSISTAT $^{\circledR}$ (Silva, 2014).

\section{RESULTS AND DISCUSSION}

The compatibility ratios at 30 months after transplantation indicate that there were no significant differences between the treatments, as shown in Table 1. The mean was above 0.9. This shows a good interaction and affinity between the rootstocks and the CNPMF 01 Tahiti acid lime clone. Citrandarin Indio was the rootstock that obtained the highest values, and Swingle Citrumelo, the lowest values. Similar values were obtained by Rodrigues et al. (2016) at their evaluation of Tahiti acid lime in 14 rootstocks under protected environmental conditions, with the exception of the Swingle Citrumelo, where the authors found values below 0.5 . These authors explain that ratings in the field were needed to confirm the incompatibility of this rootstock with Tahiti acid lime. Signs of incompatibility between a variety and a rootstock can cause rupture at the graft interface soon after the production of seedlings or years after planting, resulting in poorly developed and unproductive plants and death (Moraes et al., 2011; Oliveira et al., 2012).

Regarding the height of the plants, no differences were initially verified between rootstocks as shown in Table 2 . At 24 and 30 months after transplantation, Rangpur Santa Cruz lime combined with Citrandarins Indio and Riverside were observed to produce taller plants compared to other rootstocks.

Cintra et al. (2000) found that the Rangpur lime offers the best adaptive features to climatic conditions of the studied region. The authors report that this rootstock may suffer less stress level during periods of water deficit, especially in arid and semiarid regions with low and irregular distribution of rainfall, as occurs in most of the northeastern states. In turn, the citrandarin Riverside has faster emergence is in protected environmental conditions,

Table 1. Compatibility Ratio (CR) of the CNPMF 01 Tahiti acid lime on different rootstocks at 30 months after planting, Russas, Ceará, Brazil. 2016

\begin{tabular}{ll}
\hline \multicolumn{1}{c}{ Treatment } & \multicolumn{1}{c}{ IC } \\
\hline T1: Tahiti Acid lime x Rangpur Santa Cruz lime & $0.904 \mathrm{a}$ \\
T2: Acid lime Tahiti x Sunki Tropical Tangerine & $0.914 \mathrm{a}$ \\
T3: Tahiti Acid lime x Citrandarin Indio & $0.958 \mathrm{a}$ \\
T4: Tahiti Acid lime x Citrandarin Riverside & $0.924 \mathrm{a}$ \\
T5: Tahiti Acid lime x Swingle Citrumelo & $0.902 \mathrm{a}$ \\
C. V. $(\%)$ & 5.39 \\
Value F & $0.6228 \mathrm{~ns}$ \\
\hline
\end{tabular}

Means followed by the same letter did not differ statistically from each other (Scott-Knott - 5\% probability). ns - non-significant. 
as observed by Rodrigues et al. (2015), and that this characteristic is also correlated with the height of plants within few years after the transplantation.

At the end of the ratings, Swingle Citrumelo was observed to induce Tahiti acid lime plants to lower heights. This rootstock was the second most used between 2004 and 2007, when it was used in $20.4 \%$ of the seedlings in São Paulo; however, as this rootstock produces lower canopy volumes, it is indicated for high density crops (Pompeu Junior \& Blumer, 2008). Plants grafted on this rootstock demanding more fertilization, especially potassium supply, what might have induced such result (Bastos et al., 2014). Smaller plants can also be interesting to citriculture because they allow for a greater efficiency in phytosanitary inspections and in the application of pesticides, with consequent lower costs and less damage to the environment (Pompeu Junior, 2001).

There were significant differences between the average canopy diameters in all biometric surveys, indicating that this characteristic was affected by the treatments in this study. There was, again, a superiority of the combination
Rangpur Santa Cruz lime and Citrandarin Riverside, as shown in Table 3.

As for canopy volume $\left(\mathrm{m}^{3}\right)$, it was observed that Rangpur Santa Cruz lime combined with Citrandarin Riverside had better performance, forming vigorous and well-developed canopy cores. The significant differences between the rootstocks used with CNPMF 01 Tahiti acid lime are shown in the Table 4. Part of this effect was certainly due to the different rootstocks studied. The other treatments had no statistical differences, with the lowest average obtained in the to induction of smaller plants by Swingle Citrumelo rootstock.

Dwarf plants, or with smaller canopy volumes, are the most appropriate for high density orchards of that employ rootstocks that induce more vigorous canopies (Donadio \& Stuchi, 2001). Thus, Swingle Citrumelo would be suitable for areas such those with the conditions of the present study. However, the assessment of viability in terms of productivity is necessary for indication of the rootstock in this situation.

The combination of Tahiti acid lime scions and Rangpur Santa Cruz lime rootstocks from the point of

Table 2. Average height (m) of the CNPMF 01 Tahiti acid lime on different rootstocks at 18, 24 and 30 months after planting, Russas, Ceará, Brazil. 2016

\begin{tabular}{lccc}
\hline \multicolumn{1}{c}{ Treatment } & 18 months & 24 months & 30 months \\
\hline T1: Tahiti acid lime x Rangpur Santa Cruz lime & $1.40 \mathrm{a}$ & $1.89 \mathrm{a}$ & $2.12 \mathrm{a}$ \\
T2: Tahiti acid lime x Sunki Tropical Tangerine & $1.40 \mathrm{a}$ & $1.54 \mathrm{~b}$ & $1.71 \mathrm{~b}$ \\
T3: Tahiti acid lime x Citrandarin Indio & $1.43 \mathrm{a}$ & $1.80 \mathrm{a}$ & $2.00 \mathrm{a}$ \\
T4: Tahiti acid lime x Citrandarin Riverside & $1.47 \mathrm{a}$ & $2.05 \mathrm{a}$ & $2.12 \mathrm{a}$ \\
T5: Tahiti acid lime x Swingle Citrumelo & $1.19 \mathrm{a}$ & $1.49 \mathrm{~b}$ & $1.43 \mathrm{c}$ \\
C.V. $(\%)$ & 8.86 & 10.45 & 8.04 \\
F value & $2.37 \mathrm{~ns}$ & $5.03^{*}$ & $11.60^{* *}$ \\
\hline
\end{tabular}

Means followed by the same letter did not differ statistically from each other (Scott-Knott - 5\% probability). *significant at $5 \%$ level of probability $(\mathrm{p}<0.05)$; **significant at $1 \%$ level of probability $(\mathrm{p}<0.01)$; ns - non-significant.

Table 3. Average canopy diameter (m) of the CNPMF 01 Tahiti acid lime on different rootstocks at 18, 24 and 30 months after planting, Russas, Ceará, Brazil. 2016

\begin{tabular}{lccc}
\hline \multicolumn{1}{c}{ Treatment } & 18 months & 24 months & 30 months \\
\hline T1: Tahiti acid lime x Rangpur Santa Cruz lime & $1.90 \mathrm{a}$ & $2.58 \mathrm{a}$ & $3.58 \mathrm{a}$ \\
T2: Tahiti acid lime x Sunki Tropical Tangerine & $1.51 \mathrm{a}$ & $1.56 \mathrm{~b}$ & $2.35 \mathrm{~b}$ \\
T3: Tahiti acid lime x Citrandarin Indio & $1.45 \mathrm{a}$ & $2.28 \mathrm{a}$ & $2.71 \mathrm{~b}$ \\
T4: Tahiti acid lime x Citrandarin Riverside & $1.91 \mathrm{a}$ & $2.56 \mathrm{a}$ & $3.17 \mathrm{a}$ \\
T5: Tahiti acid lime x Swingle Citrumelo & $1.49 \mathrm{a}$ & $1.86 \mathrm{~b}$ & $2.00 \mathrm{~b}$ \\
C.V. $(\%)$ & 13.49 & 12.74 & 13.88 \\
F value & $3.17 \mathrm{~ns}$ & $7.91^{* *}$ & $8.04^{* *}$ \\
\hline
\end{tabular}

Means followed by the same letter did not differ statistically from each other (Scott-Knott $-5 \%$ probability). **significant at $1 \%$ level of probability $(\mathrm{p}<0.01) ; \mathrm{ns}-$ non-significant. 
Table 4. Volume of the canopy $\left(\mathrm{m}^{3}\right)$ of the CNPMF 01 Tahiti acid lime on different rootstocks to 18,24 and 30 months after planting, Russas, Ceará, Brazil. 2016

\begin{tabular}{lccc}
\hline \multicolumn{1}{c}{ Treatment } & 18 months & 24 months & 30 months \\
\hline T1: Tahiti Acid lime x Rangpur Santa Cruz lime & $2.72 \mathrm{a}$ & $6.62 \mathrm{a}$ & $14.40 \mathrm{a}$ \\
T2: Tahiti Acid lime x Sunki Tropical Tangerine & $1.75 \mathrm{a}$ & $1.99 \mathrm{~b}$ & $5.02 \mathrm{~b}$ \\
T3: Tahiti Acid lime x Citrandarin Indio & $1.62 \mathrm{a}$ & $5.14 \mathrm{a}$ & $7.85 \mathrm{~b}$ \\
T4: Tahiti Acid lime x Citrandarin Riverside & $2.8 \mathrm{a}$ & $6.91 \mathrm{a}$ & $11.29 \mathrm{a}$ \\
T5: Tahiti Acid lime x Swingle Citrumelo & $1.41 \mathrm{a}$ & $2.73 \mathrm{~b}$ & $3.08 \mathrm{~b}$ \\
C.V. $(\%)$ & 30.80 & 30.07 & 36.92 \\
F value & $3.17 \mathrm{~ns}$ & $7.54 * *$ & $6.68^{* *}$ \\
\hline
\end{tabular}

Means followed by the same letter did not differ statistically from each other (Scott-Knott - 5\% probability). **significant at $1 \%$ level of probability $(\mathrm{p}<0.01)$; ns - non-significant.

view of vegetative traits seems interesting (Table 4), but produces short lived plants due to their high vulnerability to Phytophthora spp. gummosis, which has been confirmed in a rootstock experiment conducted at the citriculture Experimental Station of Trough, where all Rangpur lime plants were killed, mainly by gummosis, after nine years of planting (Stuchi \& Cyrillo, 1998).

Rangpur Santa Cruz lime has strong potential for the arid areas due to its better physiological behavior and more efficient use of water and biomass production. However, the susceptibility to Phytophthora spp. gummosis, which has decimated the majority of the sweet orange orchards in the Jaguaribe Valley, represents an obstacle to use of this rootstock in Ceará (Medina Filho et al., 2003).

\section{CONCLUSION}

Rangpur Santa Cruz lime and Citrandarin Riverside were the rootstock treatments that induced most vigorous canopies of CNPMF 01 Tahiti acid lime in the edaphoclimatic conditions of the semiarid area studied, showing better adaptation and vegetative development in the initial period of plantation of citrus orchards. However, in view of the susceptibility of Rangpur Santa Cruz lime to biotic and abiotic stresses, the adoption of Citrandarin Riverside is recommended as an alternative under similar conditions.

\section{ACKNOWLEDGEMENTS}

The authors acknowledge to Embrapa Semiarido, Embrapa Mandioca e Fruticultura Tropical and Nucleo de Pesquisa em Citros (NPC), by supporting the Revitalization Program of Citriculture in the Vale do Jaguaribe, Ceará.

\section{REFERENCES}

Almeida CO \& Passos OS (2011) Citricultura brasileira: em busca de novos rumos desafios e oportunidades na região Nordeste. Cruz das Almas: Embrapa Mandioca e Fruticultura. $160 \mathrm{p}$.

Bastos DC, Ferreira EA, Passos OS, Sá JF, Ataíde EM \& Calgaro M (2014) Cultivares copa e porta-enxertos para a citricultura brasileira. Informe Agropecuário 35(281): $36-45$.

Cintra FLD, Libardi PL \& Saad AM (2000) Balanço hídrico no solo para porta-enxertos de citros em ecossistema de tabuleiro costeiro. Revista Brasileira de Engenharia Agrícola e Ambiental 4(1): 23-28.

Cunha Sobrinho AP, Magalhães AFJ, Souza AS, Passos OS \& Soares Filho WS (2013) Cultura dos citros. Brasília: Embrapa Informação Tecnológica. 399 p.

Donadio LC \& Stuchi ES (2001) Adensamento de plantio e ananicamento em citros. Jaboticabal: FUNEP. 75 p.

Durigan MFB, Mattiuz BH \& Durigan JF (2005) Injúrias mecânicas na qualidade pós-colheita de lima ácida 'Tahiti' armazenada sob condição ambiente. Revista Brasileira de Fruticultura 27(3): 369-372.

Fallahi E \& Rodney DR (1991) Tree size, fruit quality, and leaf mineral nutrient concentration of Fairchild mandarin on six rootstocks. Journal of the American Society for Horticultural Science 116(1): 2-5.

Medina Filho HP, Bordignon R, Siqueira WJ, Feichtenberger E, Carvalho MRT \& Teófilo Sobrinho J (2003) Resistência de clones e híbridos de porta-enxertos de citros à gomose de tronco causada por Phytophthora parasitica. Fitopatologia Brasileira 28: 534-540. 
Moraes LAC, Moreira A\& Pereira JCR (2011) Incompatibility of 'Cleopatra' mandarin rootstock for grafting citrus in Central Amazon, State of Amazonas, Brazil. Revista de Ciências Agrárias. 54: 299-306.

Oliveira ERM, Souza EDS, Girardi EA, Soares Filho WS, Santos MG \& Passos OS (2012) Incompatibilidade de combinações copa e porta-enxerto de citros. Anais do XXII Congresso Brasileiro de Fruticultura, Bento Gonçalves, RS, p. 3656-3660.

Passos OS, Soares Filho WS, Barbosa CJ \& Cunha Sobrinho AP (2013) Clones de laranjeira 'DE Russas'. Cruz das Almas: Embrapa Mandioca e Fruticultura. 4 p.

Pompeu Junior J \& Blumer S (2008) Laranjeiras e seus porta-enxertos nos viveiros de mudas cítricas do Estado de São Paulo. Revista Laranja 29(1-2): 35-50.

Pompeu Junior J (2001) Porta-enxertos para citros potencialmente ananicantes. Revista Laranja 22(1): 147-155.

Ribeiro AC, Guimarãez PT \& Alvarez VH (1999) Recomendação para o uso de corretivos e fertilizantes para o Estado de Minas Gerais. Viçosa: CFSEMG. $5^{\text {a }}$ aproximação.

Rodrigues MJS, Ledo CAS, Girardi EA, Lucas AH \& Soares Filho WS (2015) Caracterização de frutos e propagação de porta-enxertos híbridos de citros em ambiente protegido. Revista Brasileira de Fruticultura 37(2): 457-470.
Rodrigues MJS, Oliveira ERM, Girardi EA, Ledo CAS $\&$ Soares Filho WS (2016) Citrus nursery tree production using different scion and rootstock combinations in screen house. Revista Brasileira de Fruticultura 38(1): 187-201.

Silva FAS (2014) ASSISTAT-Assistência Estatística-versão 7.7. Beta (pt): programa computacional. Campina Grande: Universidade Federal de Campina Grande.

Simonetti LM (2015) Avaliação de novos híbridos de porta-enxertos para a laranjeira 'Valência'. Tese de Doutorado, Universidade Estadual Paulista "Júlio de Mesquita Filho", Jaboticabal.

Soares Filho WS, Barbosa CJ, Cunha Sobrinho AP \& Abreu EFM (2012) Limeira Ácida 'Tahiti CNPMF 01'. Cruz das Almas: Embrapa Mandioca e Fruticultura. 4 p.

Sombra KES, Silva ACC, Sombra Júnior CA, Bastos DC \& Passos OS (2015) Citricultura desenvolvida na agricultura de base familiar do município de Russas, Ceará. Anais do X Congresso Regional da Sociedade Brasileira de Economia, Administração e Sociologia Rural no Nordeste, Arapiraca, AL. 65 p.

Stuchi ES \& Cyrillo FLL (1998) Lima ácida "Tahiti”. Jaboticabal: FUNEP. 35 p.

Trucom C (2004) O poder da cura do limão. 2. ed. São Paulo: Ed. Alaúde.

Received: November 15, 2016 Accepted: October 23, 2017 